\title{
Osteopoikilosis associated with keloids formation, rheumatoid arthritis, myasthenia, Graves' disease and megaloblastic anaemia
}

\author{
Osteopoikilia skojarzona z powstawaniem bliznowców, reumatoidalnym \\ zapaleniem stawów, miastenia, chorobą Gravesa i Basedowa oraz \\ z niedokrwistością z niedoboru witaminy $B_{12}$
}

\author{
Irena Zimmermann-Górska \\ Poznan University of Medical Sciences, Poznan, Poland \\ Chair of Rheumatology, College of Education and Therapy, Poznan, Poland \\ Uniwersytet Medyczny im. Karola Marcinkowskiego w Poznaniu \\ Katedra Reumatologii Wyższej Szkoły Edukacji i Terapii w Poznaniu
}

Key words: osteopoikilosis, keloids, associated autoimmune diseases.

Słowa kluczowe: osteopoikilia, bliznowce, towarzyszące choroby autoimmunologiczne.

\section{Sum mary}

Osteopoikilosis is an uncommon hereditary dysplasia of skeleton characterized by small sclerotic foci clustered mainly in periarticular osseus regions. The radiographic pattern is pathognomonic. The disease can be a result of the loss-of-function mutations in LEMD3 - the gene responsible for bone density which can influence also on the expression of transforming growth factor $\beta 1$ (TGF- $\beta 1$ ) signalling. TGF- $\beta 1$ is a key mediator of fibrosis and a modulator of immune responses. Patients with osteopoikilosis demonstrate a higher incidence of keloid formation and autoimmune diseases. In the presented case osteopoikilosis was associated with keloids formation and autoimmune diseases: rheumatoid arthritis, myasthenia, Graves' disease and megaloblastic anaemia.

\section{Introduction}

Osteopoikilosis (OPK) - a skeletal dysplasia described by Albers-Schönberg in 1915 - is characterised by the formation of densities in cancellous bone tissue, visible on imaging studies as speckles or streaky shadows located

\section{Streszczenie}

Osteopoikilia jest rzadką, uwarunkowaną genetycznie dysplazją szkieletu, do której objawów należy powstawanie zagęszczeń kostnych - szczególnie w okolicach przystawowych - widocznych na radiogramach w postaci cieni plamistych lub pasmowatych. Występowanie osteopoikilii wiąże się z mutacją genu LEMD3 odpowiedzialnego za gęstość mineralną kości. Gen ten wpływa także na ekspresję transformującego czynnika wzrostu $\beta 1$ (transforming growth factor $\beta 1$-TGF- $\beta 1$ ), który ma kluczowe znaczenie $w$ procesie włóknienia oraz działanie immunosupresyjne i przeciwzapalne. Chorzy z osteopoikilią wykazują skłonność do nadmiernego bliznowacenia tkanek (bliznowce), obserwuje się u nich również występowanie chorób towarzyszących o podłożu autoimmunologicznym. W opisanym przypadku osteopoikilii towarzyszyło powstawanie bliznowców oraz objawy czterech chorób autoimmunologicznych: reumatoidalnego zapalenia stawów, miastenii, choroby Gravesa i Basedowa oraz niedokrwistości megaloblastycznej.

\section{Wstęp}

Osteopoikilia (OPK) - opisana przez Albers-Schönberga w 1915 r. dysplazja szkieletu - polega na powstawaniu w tkance kostnej gąbczastej zagęszczeń widocznych $w$ badaniach obrazowych $w$ postaci cieni plamistych

Address for correspondence:

Prof. Irena Zimmermann-Górska, ul. Libelta 22/7, 61-707 Poznań, e-mail: zimmermanngorska@hotmail.com

Submitted: 20.03.2014 
primarily in the area of the joints [1-3]. The condition is genetic in nature, showing autosomal dominant inheritance, with prevalence in the general population estimated at 1 in 50000 [1]. The majority of OPK cases are asymptomatic, however $15-20 \%$ of patients experience pain or joint inflammation [3]. Bone lesions are generally identified incidentally when imaging studies are performed for unrelated indications, usually post-trauma.

Attempts had been made over a number of years to identify the cause of OPK and many hypotheses had been put forward to account for the bone abnormalities. In 2004, Hellemans et al. $[4,5]$ determined that the aetiology of the disorder is linked to a mutation in the LEMD3 gene (locus 12q14). Later, Baasanjav et al. also established the presence of mutations of this gene in members of a family with OPK [6]. In view of the finding that LEMD3 is an antagonist of transforming growth factor $\beta 1$ (TGF- $\beta 1$ ), its mutation may be associated with increased expression of this cytokine and may contribute to the formation of excess fibrous tissue $[2,4,7]$. It has been noted that patients with OPK have a predisposition toward keloid formation $[2,8]$.

Back in 1992, we presented the case of a young female patient with rheumatoid arthritis (RA) whose radiographs showed lesions consistent with OPK [9]. Joint alloplasty of the knees had been followed by excessive fibrous tissue formation which led to the patient developing post-operative periarticular contractures. Repeat surgery resulted in a recurrence of this complication, the severity of the contractures gradually increased and caused severe disability. In addition to a predisposition toward excess fibrous tissue formation, observations show patients with OP have many concurrent conditions - primarily RA [9-11].

The subject of our present report is a patient with OPK consulted in 2013 who had developed keloids following vaccination against tuberculosis and a surgical procedure and had also developed symptoms of RA, myasthenia, Graves' disease, and vitamin $B_{12}$ deficiency anaemia.

\section{Case report}

A female patient, aged 36, diagnosed with RA and treated since 1995 (19 years). Inflammatory changes were located primarily in the proximal interphalangeal and metacarpophalangeal joints of the hands, and the wrists; periodical pain appeared in the shoulder and knee joints. Initial and subsequent radiographs of the joints had shown the presence of lesions typical of spotted form of OP. Initially, the patient had been treated with methotrexate, glucocorticosteroids (GCS), and non-steroidal anti-inflammatory drugs (NSAIDs). Methotrexate was, however, discontinued after several months due to poor tolerance. lub pasmowatych, umiejscowionych przede wszystkim w okolicach stawów [1-3]. Choroba jest uwarunkowana genetycznie, zależna od autosomalnego, dominującego typu dziedziczenia, w ogólnej populacji występuje z częstością ok. 1 : 50000 [1]. W większości przypadków OPK jest bezobjawowa, ale u 15-20\% chorych towarzyszy jej ból lub zapalenie stawów [3]. Zmiany w kościach najczęściej są wykrywane przypadkowo, gdy wykonuje się badania obrazowe z innych wskazań - przeważnie stanów pourazowych.

Przez wiele lat usiłowano wykryć przyczynę OPK, wysuwano wiele hipotez dotyczących zaburzeń w obrębie tkanki kostnej. W 2004 r. Hellemans i wsp. [4, 5] stwierdzili, że etiologia choroby związana jest z mutacją genu LEMD3 (locus 12q14). Mutacje tego genu w rodzinie chorych z OPK wykazali także później Baasanjav i wsp. [6]. Z uwagi na stwierdzenie, że LEMD3 jest antagonistą transformującego czynnika wzrostu (transforming growth factor $\beta 1$ - TGF- $\beta 1$ ), jego mutacja może się łączyć ze zwiększoną ekspresją tej cytokiny i przyczyniać się do nasilonego procesu włóknienia tkanek [2, 4, 7]. Zauważono, że u chorych z OPK dochodzi do powstawania bliznowców [2, 8].

W 1992 r. opisaliśmy przypadek młodej chorej na reumatoidalne zapalenie stawów (RZS), u której w badaniu radiograficznym widoczne były zmiany odpowiadające OPK [9]. Po wykonaniu u chorej aloplastyki stawów kolanowych wokót operowanych stawów doszło do wytworzenia się obfitej masy tkanki włóknistej powodującej przykurcze. Powtórna operacja spowodowała ponownie to powikłanie, przykurcze stopniowo narastały i były przyczyną ciężkiego kalectwa. Oprócz tendencji do włóknienia tkanek, u chorych z OPK zauważono występowanie wielu chorób wspótistniejących, przede wszystkim RZS [9-11].

W 2013 r. konsultowano chorą z OPK, u której doszło do powstania bliznowców po szczepieniu przeciwgruźliczym i zabiegu chirurgicznym, a ponadto wystąpiły objawy RZS, miastenii, choroby Gravesa i Basedowa oraz niedokrwistość z niedoboru witaminy $\mathrm{B}_{12}$.

\section{Opis przypadku}

Chora, lat 36, od 1995 r. (przez 19 lat) leczona z rozpoznaniem RZS. Zmiany zapalne obejmują głównie stawy międzypaliczkowe bliższe palców rąk, śródręczno-paliczkowe i nadgarstkowe, ból pojawia się okresowo w stawach barkowych i kolanowych. Zdjęcia RTG stawów wykazywały od początku choroby zmiany w kościach typowe dla plamistej postaci OPK. Chora była początkowo leczona metotreksatem, glikokortykosteroidami (GKS) i niesteroidowymi lekami przeciwzapalnymi (NLPZ). Metotreksat odstawiono jednak po kilku miesiącach z powodu złej tolerancji. 
In addition to symptoms of joint inflammation, in 1999 the patient presented with a very significant decrease in muscular force, impaired speech, and blepharoptosis. At that time, she had been admitted to the Neurology Department of the J. Strus Memorial Hospital in Poznan, where computer tomography revealed the presence of a vestigial thymus and electromyography detected signs of myasthenia. Subsequently, the patient was referred to the Pulmonary Hospital in Zakopane with a diagnosis of myasthenia, where she underwent a thymectomy. A keloid developed at the surgical site. In 2001, diagnosed with Graves-Basedow disease, the patient was treated with iodine 131 for symptoms of hyperthyroidism at the Endocrinology Clinic of the Medical Academy in Poznan. Following treatment, she developed hypothyroidism, which required hormone replacement therapy. In 2010, the patient was diagnosed with vitamin $B_{12}$ deficiency anaemia (treated at the Department of Internal Medicine of a hospital in Pleszew).

The present physical examination revealed the patient is overweight and has keloids in the thymectomy scar and at the site of an old scar that formed following vaccination against tuberculosis (Fig. 1a, b). Interosseous muscle atrophy is present in both hands as well as swelling of the metacarpophalangeal and proximal interphalangeal joints of digits II to V bilaterally; she has a substantially limited range of motion and pain in both carpal joints and pain upon movement of the right shoulder joint.

Diagnostically significant findings of laboratory investigations were the presence of IgM-rheumatoid factor at a level of $167 \mathrm{RU} / \mathrm{ml}$ and of anti-citrullinated peptide antibodies $-79.2 \mathrm{RU} / \mathrm{ml}$.

The result of the complete blood count (prior to vitamin $B_{12}$ therapy) was as follows: WBC $-6.0 \mathrm{~K} / \mu \mathrm{l}$, RBC $-2.39 \mathrm{M} / \mu \mathrm{l}, \mathrm{HGB}-9.0 \mathrm{~g} / \mathrm{dl}$, HCT - 26.1\%, MCV - $109.2 \mathrm{fl}$, MCH - 37.7 pg, MCHC - $34.5 \mathrm{~g} / \mathrm{dl}$, PLT - $114.0 \mathrm{~K} / \mu \mathrm{l}$, RDW $-17.7 \%$, PDW - $13.9 \mathrm{fl}, \mathrm{MPV}-11.5 \mathrm{fl}$, and P-LCR - 34.8\%.

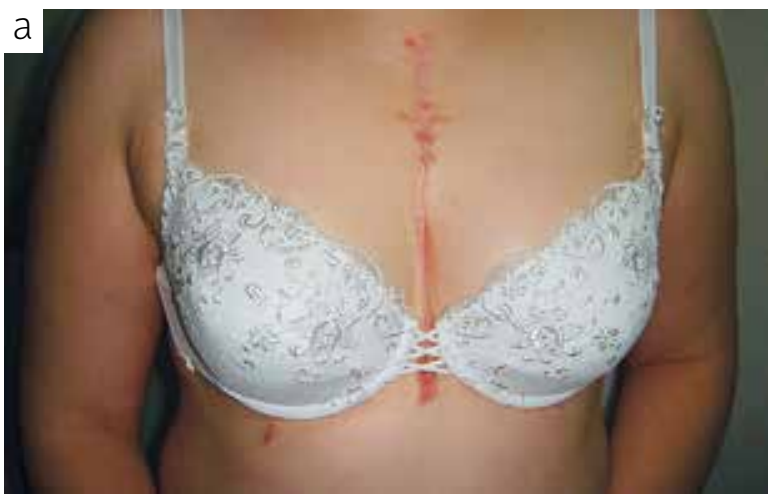

Fig. 1a. Keloid which appeared after thymectomy. Ryc. 1a. Bliznowiec powstaty po tymektomii.
W 1999 r. oprócz objawów zapalenia stawów wystąpito bardzo znaczne osłabienie siły mięśniowej, zaburzenia mowy i opadanie powiek. Chora przebywała wówczas na Oddziale Neurologii Szpitala im. J. Strusia w Poznaniu, gdzie metodą tomografii komputerowej wykazano obecność szczątkowej grasicy, a badaniem elektromiograficznym stwierdzono cechy miastenii. Z rozpoznaniem miastenii chora została następnie skierowana do Szpitala Specjalistycznego Chorób Płuc w Zakopanem i poddana tymektomii. Po zabiegu wytworzył się bliznowiec. W 2001 r. chora była leczona jodem 131 z powodu objawów nadczynności tarczycy, z rozpoznaniem choroby Gravesa i Basedowa, w Klinice Endokrynologii Akademii Medycznej w Poznaniu. Po leczeniu wystąpiła niedoczynność tarczycy wymagająca stosowania hormonów. W 2010 r. rozpoznano u chorej niedokrwistość związaną z niedoborem witaminy $\mathrm{B}_{12}$ (leczona na Oddziale Chorób Wewnętrznych Szpitala w Pleszewie).

Obecnie badaniem przedmiotowym stwierdzono nadwagę, w bliźnie pooperacyjnej po tymektomii i w bliźnie powstałej przed laty po wykonaniu szczepienia przeciw gruźlicy widoczne są bliznowce (ryc. 1a, b). W obrębie rąk stwierdzono zanik mięśni międzykostnych, obrzęk stawów śródręczno-paliczkowych i międzypaliczkowych bliższych palców od II do V obu rąk, znacznie ograniczoną ruchomość i bolesność obu stawów nadgarstkowych, bolesność ruchową stawu barkowego prawego.

W badaniach laboratoryjnych o znaczeniu diagnostycznym wykazano obecność czynnika reumatoidalnego w klasie IgM o stężeniu 167 RU/ml i przeciwciał przeciw cytrulinowanym peptydom - 79,2 RU/ml.

Badanie morfologii krwi (przed leczeniem witaminą

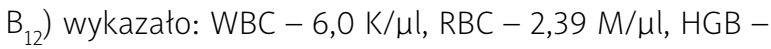
9,0 g/dl, HCT - 26,1\%, MCV - 109,2 fl, MCH - 37,7 pg, MCHC - 34,5 g/dl, PLT - 114,0 K/ul, RDW - 17,7\%, PDW - 13,9 fl, MPV - 11,5 fl, P-LCR - 34,8\%. Po rozpoczęciu

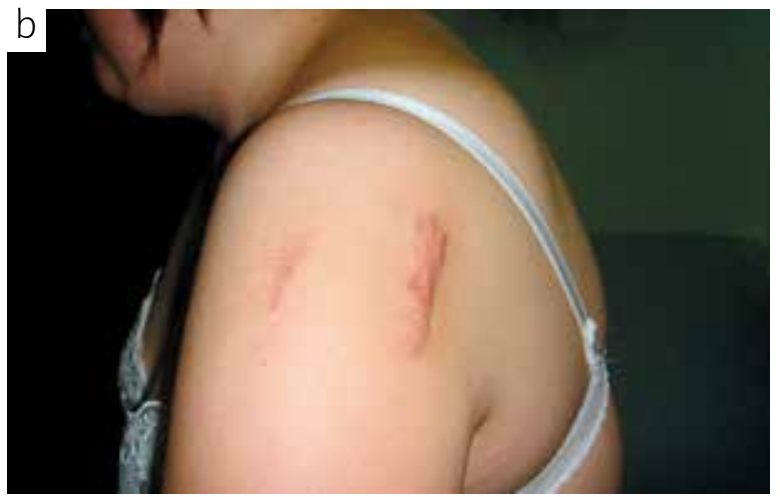

Fig. 1b. Keloid which appeared after the vaccination against tuberculosis (in childhood).

Ryc. 1b. Bliznowiec powstaty w miejscu szczepienia przeciw gruźlicy (w dzieciństwie). 

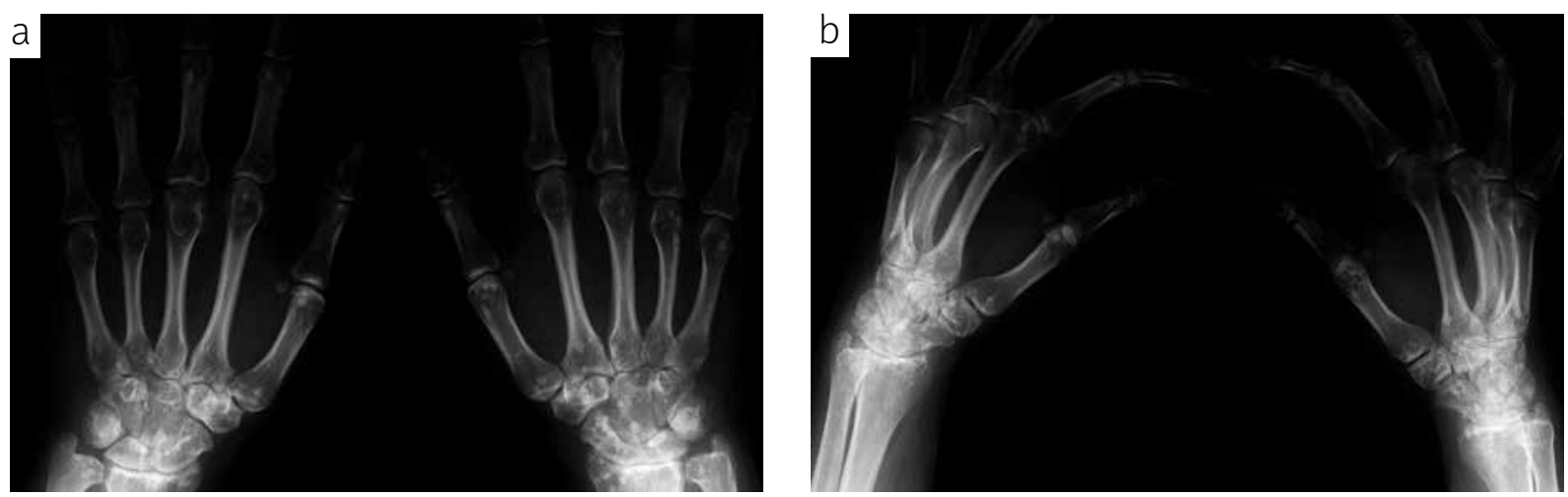

Fig. 2a, b. Bilateral radiographs of the hands - typical extensive changes for rheumatoid arthritis in wrists and numerous sclerotic lesions in the bones related to OPK.

Ryc. 2a, b. Zdjęcia stawów rąk - zaawansowane zmiany typowe dla RZS w nadgarstkach, liczne plamiste zagęszczenia w kościach związane z OPK.

Once treatment had been initiated, a gradual normalisation of blood count parameters was observed.

Recently obtained radiological images of the joints of the hands revealed findings consistent with stage III/IV RA, particularly within the wrist joints, accompanied by bony densities typical of spotted form of OP (Fig. 2a, b). Images of the feet and ankle joints revealed changes associated with OP (Fig. 3a-d).

The patient is currently on maintenance doses of GCS (metypred $6.0 \mathrm{mg} /$ day), vitamin $B_{12}$, euthyrox and, periodically, NSAIDs. The course of her RA is characterised by periods of inflammatory exacerbation and remission, requiring adequate modification of treatment including disease-modifying antirheumatic drugs.

\section{Discussion}

As mentioned above, in addition to a predisposition towards excess fibrous tissue formation, observations show patients with OP have many co-existing comorbidities. To date, no studies have addressed the issue of the prevalence of such associations or explained their causes. The isolated reports we do have at our disposal indicate further investigation into these associations is warranted.

Osteopoikilosis occurs concurrently with internal organ fibrosis (liver), malignant neoplasms, and autoimmune diseases. Reports have described cases of concurrent OPK and RA [9-11], as well as comorbidity involving RA and symptoms of Sjögren's syndrome [12], systemic lupus erythematosus [13], and discoid lupus erythematosus [14]. Osteopoikilosis is known to occur in association with symptoms of systemic sclerosis $[15,16]$, keloid formation $[7,16]$, and with seronegative spondyloartropathy $[17,18]$. To date, there have been no reported cases of OPK occurring concurrently with the autoimmune diseases diagnosed in the patient presented in this paper. leczenia nastąpiła stopniowa normalizacja obrazu morfologicznego krwi.

Zdjęcia rentgenowskie stawów rąk wykazały ostatnio zmiany odpowiadające III/IV okresowi RZS, szczególnie w stawach nadgarstkowych, i towarzyszące im zagęszczenia tkanki kostnej typowe dla plamistej postaci OPK (ryc. 2a, b). Zdjęcia stawów stóp i stawów skokowych uwidoczniły zmiany związane z OPK (ryc. 3a-d).

Chora otrzymuje podtrzymujące dawki GKS (metypred 6,0 mg/dobę), witaminę $B_{12}$, eutyroks, okresowo NLPZ. W przebiegu RZS obserwuje się okresy nasilenia objawów zapalnych i okresy remisji wymagające odpowiedniej modyfikacji leczenia (m.in. lekami modyfikującymi przebieg choroby).

\section{Dyskusja}

Jak wspomniano wyżej, u chorych z OPK oprócz zwiększonej skłonności do włóknienia tkanek obserwuje się wspótistnienie wielu chorób towarzyszących. Nie ma do tej pory badań dotyczących częstości występowania tych skojarzeń ani wyjaśnienia ich przyczyny. Dysponujemy opisami pojedynczych przypadków, które wskazują jednak na celowość dalszego śledzenia tego zjawiska.

Osteopoikilii towarzyszą stany z nasilonym włóknieniem narządów (wątroba), nowotwory złośliwe oraz choroby autoimmunologiczne. Opisywano równoczesne występowanie OPK i RZS [9-11], a także RZS skojarzonego z objawami zespołu Sjögrena [12], tocznia rumieniowatego układowego [13] i tocznia rumieniowatego krążkowego [14]. Osteopoikilia łączyła się z objawami twardziny układowej $[15,16]$, powstawaniem bliznowców $[7,16]$ oraz ze spondyloartropatiami seronegatywnymi $[17,18]$. Dotychczas nie obserwowano kojarzenia się OPK z chorobami autoimmunologicznymi rozpoznanymi w opisanym obecnie przypadku. 

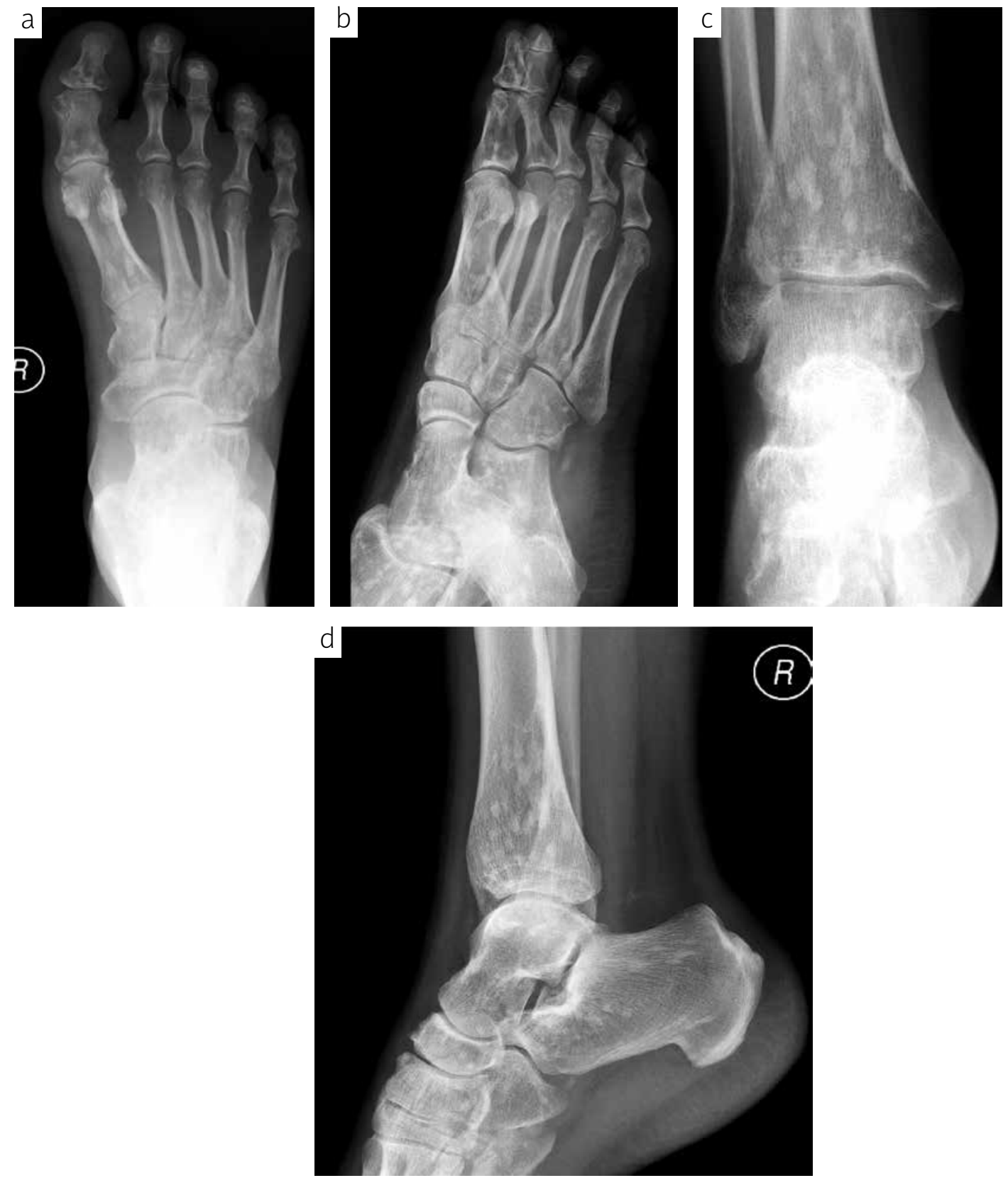

Fig. 3a-d. Radiographs of the right foot and the right ankle-multiple - sclerotic lesions in bones.

Ryc. 3a-d. Zdjęcia prawej stopy i prawego stawu skokowego - liczne plamiste cienie w obrębie kości.

TGF- $\beta 1$ may be a factor involved in the concurrent occurrence of OPK and other conditions described above. As mentioned earlier, LEMD3 gene mutations may affect expression of this cytokine.

The systemic activity of TGF- $\beta 1$ is multidirectional. The cytokine is a primary regulator of fibrogenesis in normal as well as in damaged tissue (the process of healing); it stimulates extracellular matrix synthesis and inhibits metalloproteinase production [19-22]. In addition, TGF- $\beta 1$ plays
Transformujący czynnik wzrostu $\beta 1$ może uczestniczyć w powstawaniu wymienionych wyżej skojarzeń OPK z innymi chorobami. Jak już wspomniano, mutacje genu LEMD3 mogą wpływać na ekspresję tej cytokiny.

Działanie TGF- $\beta 1$ w ustroju jest wielokierunkowe. Cytokina ta jest głównym regulatorem fibrogenezy - zarówno w stanie prawidłowym, jak i w uszkodzeniach tkanek (proces gojenia), stymuluje syntezę macierzy pozakomórkowej, a hamuje produkcję metaloproteinaz [19-22]. Odgrywa po- 
a role in angiogenesis, regulates bone remodelling while simultaneously displaying anti-inflammatory and immunosuppressive activity $[23,24]$. Documented effects of TGF- $\beta 1$ include, among others, inhibition of NK cell cytotoxic activity and modulation of B- and T-lymphocyte differentiation and proliferation [22, 25]. TGF- $\beta 1$ coding gene-deficient mice produce anti-nuclear antibodies, immunologica complexes, and develop multiple organ inflammation [26]. Significant reductions in serum TGF- $\beta 1$ levels have been reported in patients with systemic lupus erythematosus and also in the course of Hashimoto's disease [13].

Genetic and molecular biology studies being conducted in many centres are gradually advancing our understanding of the etiopathogenesis of the above mentioned diseases and the reasons behind their concurrent occurrence.

The case presented in this report is noteworthy because of the unusual co-existence of autoimmune diseases with OPK combined with a tendency to develop keloids. Moreover, this report provides further evidence that patients with OPK may develop post-operative complications associated with scar development. Procedures performed in the area of the joints carry a particularly high risk because - as in the previously presented case report - they can lead to joint immobilisation and disability [9].

Author declares no conflict of interest.

\section{References}

\section{Piśmiennictwo}

1. Benli IT, Akalin S, Boysan E, et al. Epidemiological, clinical and radiological aspects of osteopoikilosis. J Bone Joint Surg 1991; 74: 504-506.

2. Sarralde A, Garcia-Cruz D, Nazara Z, Sanchez-Corona J. Osteopoikilosis: Report of a familial case. Genet Counsel 1994; 5: 373-375.

3. Borman P, Özoran K, Aydoğ Ş, Coşkun S. Osteopoikilosis: report of a clinical case and review of the literature. Joint Bone Spine 2002; 69: 230-233.

4. Baasanjav S, Jamsheer A, Kolanczyk M, et al. Osteopoikilosis and multiple exostoses caused by novel mutations in LEMD3 and EXT1 genes respectively - coincidence in one family. BMC Med Genet 2010; 11: 110-117.

5. Ben-Asher E, Zelzer E, Lancet D. LEMD3: the gene responsible for bone density disorders (osteopoikilosis). IMAJ 2005; 7: 273-274.

6. Hellemans J, Preobrazhenska O, Willaert A, et al. Loss-of-function mutations in LEMD3 result in osteopoikilosis, Buschke-Ollendorff syndrome and melorheostosis. Nat Genet 2004; 36: 1213-1218. nadto rolę w angiogenezie, wpływa na przebudowę tkanki kostnej, a równocześnie wykazuje działanie przeciwzapalne i immunosupresyjne $[23,24]$. Udowodniono m.in., że hamuje ona aktywność cytotoksyczną komórek NK oraz moduluje różnicowanie i proliferację limfocytów B i T [22, 25]. U myszy pozbawionych genu kodującego TGF- $\beta 1$ dochodzi do wytwarzania przeciwciał przeciwjądrowych, powstawania kompleksów immunologicznych i do wielonarządowych zmian zapalnych [26]. W surowicy chorych na toczeń rumieniowaty układowy, a także w przebiegu choroby Hashimoto wykazano istotne zmniejszenie stężenia TGF- $\beta 1[13]$.

Badania z zakresu genetyki i biologii molekularnej prowadzone w wielu ośrodkach pozwalają stopniowo poznawać etiopatogenezę wymienionych wyżej chorób i przyczyny ich kojarzenia się ze sobą.

Przypadek przedstawiony w niniejszym opracowaniu zasługuje na uwagę w związku z niezwykłym współistnieniem chorób autoimmunologicznych towarzyszących OPK z równoczesną skłonnością do tworzenia bliznowców. Opis ten jest ponadto kolejnym dowodem, że u osób z OPK mogą nastąpić powikłania zabiegów chirurgicznych związane z powstającą blizną. Zagrożenie to dotyczy przede wszystkim zabiegów wykonywanych w obrębie stawów, ponieważ - tak jak u poprzednio opisanej chorej - może dojść do ich unieruchomienia i do kalectwa [9].

\section{Autorka deklaruje brak konfliktu interesów.}

7. Mumm S, Wenkert D, Zhang X, et al. Deactivating germline mutations in LEMD3 cause osteopoikilosis and BuschkeOllendorff syndrome, but not sporadic melorheostosis. J Bone Min Res 2007; 22: 243-250.

8. Raskin MM. Osteopoikilosis: possible association with dystocia and keloid. South Med J 1975; 68: 270-278.

9. Zimmermann-Górska I, Włodarczyk R, Jakubowski S. Nadmierne bliznowacenie tkanek po plastyce totalnej stawów kolanowych u chorej na reumatoidalne zapalenie stawów z równoczesną osteopoikilią. Reumatologia 1992; 30: 249-255.

10. Cazzola M, Caruso I, Montrare F, et al. Rheumatoid arthritis associated with osteopoikilosis: a case report. Clin Exp Rheumatol 1989; 7: 423-426.

11. Zajdel J, Zajdel R. Reumatoidalne zapalenie stawów u chorej z osteopoikilią. Wiad Lek 1996; 49: 7-12.

12. Ureten K. Osteopoikilosis in a patient with rheumatoid arthritis complicated with dry eyes. Rheumatol Int 2007; 27: 10791082.

13. Manolova I, Gerenova J, Ivanova M. Serum levels of transforming growth factor- $\beta 1$ (TGF- $\beta 1$ ) in patients with systemic lupus erythematosus and Hashimoto thyroiditis. Eur Cytokine Netw 2013; 24: 69-74. 
14. Bicer A, Tursen K, Ozer C, et al. Coexistence of osteopoikilosis and discoid lupus erythematosus: a case report. Clin Rheumatol 2012; 10: 405-407.

15. Asano Y, Ihn H, Yamane K, et al. Impaired Smad7-Smurf-mediated negative regulation of TGF- $\beta$ signalling in scleroderma fibroblasts. J Clin Invest 2004; 113: 253-264.

16. Igarashi A, Nashiro K, Kikuchi K, et al. Connective tissue growth factor gene expression in tissue sections from localized scleroderma, keloid, and other fibrotic skin disorders. J Invest Dermatol 1996; 106: 729-733.

17. Sari I, Simsek I, Guvenc I, et al. Osteopoikilosis coexistence with ankylosing spondylitis and familial Mediterraen fever. Rheumatol Int 2009; 29: 321-323.

18. Ruaro B, Sulli A, Alessandri E, et al. Coexistence of osteopoikilosis with seronegative spondyloarthritis and Raynaud's phenomenon: first case report with evaluation of the nailfold capillary bed and literature review. Reumatismo 2012; 64: 335-339.

19. Denton CP, Abraham DJ. Transforming growth factor-beta and connective tissue growth factor: Key cytokines in scleroderma pathogenesis. Curr Opin Rheumatol 2001; 13: 505-511.

20. Ihn H. Pathogenesis of fibrosis: role of TGF $\beta$ and CTGF. Curr Opin Rheumatol 2002; 14: 681-685.

21. Leask A, Abraham DJ. TGF- $\beta$ signalling and the fibrotic response. The FASEB Journal 2004; 18: 816-827.

22. Mauviel A. Transforming growth factor-beta: a key mediator of fibrosis. Methods Mol Med 2005; 117: 69-80.

23. Li Mo, Wan YY, Sanjabi S, et al. Transforming growth factor-beta regulation in immune responses. Ann Bev Immunol 2006; 24: 99-146.

24. Yoshimura A, Muto G. TGF- $\beta$ function in immune suppression in: Current Topics in Microbiology and Immunology. Ahmed R, Honjo T (eds.), Negative-Co-Receptors and Ligands. Springer Berlin-Heilderberg, 2011.

25. Wu J, Xie A, Chen W. Cytokine regulation of immune tolerance. Burns \& Trauma 2014; 2: 11-17.

26. Letterio JJ, Geiser AG, Kulkarni AB. Autoimmunity associated with TGF- $\beta$-1-deficiency in mice is dependent on MHC class II antigen expression. J Clin Invest 1996; 98: 2109-2119. 